\title{
Speech Act of "Touch" Therapy in the Intervention Service Foundation For Autism and Developmental Delay (YISADDI) in the Method of Traffic Light Games
}

\author{
Maria Kartika Nababan', Syahnan Daulay ${ }^{2}$, Wisman Hadi \\ ${ }^{l}$ Master Student in State University of Medan (Unimed), Medan, Indonesia \\ ${ }^{2}$ Lecturer in State University of Medan (Unimed), Medan, Indonesia \\ maria.kartika08@gmail.com
}

\begin{abstract}
An autistic is a child of his own world. They experience interference in verbal and nonverbal language. Therapy given to children with autism is one of the right treatments to help them understand the right language and behavior. This study aims to describe the form and function of speech acts, speech action strategies, speech act selection, and achievement of therapist's "tactile" speech acts in clinical interventions for autistic children using the red light, green light play method. This study uses a qualitative approach with a clinical pragmatic approach. The results of the study are as follows. First, the clinical intervention therapist for children with autism uses a simple type of directive action and consists of one word, namely commanding speech, inviting / encouraging, rejecting / prohibiting, asking, and agreeing as well as expressive speech acts, namely expressions of praise and gratitude. Second, the therapist's language action strategy is a direct speech strategy by calling, giving instructions, and using visuals or models. Third, the therapy chooses speech acts using the S.P.E.A.K.I.N.G component with the help of PEC or compic media for effective communication. Fourth, therapists use speech acts that are accompanied by facial expressions, intonations, pats on the child's body so that children with autism are more focused and understand the purpose of communication.
\end{abstract}

Keywords: speech act; therapist; clinical intervention; autistic children

\section{Introduction}

Language disorder (language disorder) in a child caused by abnormalities in the context of the language fields that underlie language. For example, pragmatic language damage, which is the difficulty of using language in a context that often, occurs in children with autism or people with intellectual disabilities. Simanjuntak (2009: 248) explains that grammar, especially syntax, the language of autistic people is very limited, strange, as well as the sound is rather disturbing to the ear, hoarse, like whispering, and so on. Too often the repetition of words is excessive or stops suddenly in the middle of a conversation such as losing something that is difficult to find again.

National Institute of Mental Health (2008) defines that autism is one of the developmental disorders of children. Autism disorder is at least shown by the lack of ability of children to the ability of social interaction, verbal communication, and the presence of repetitive behavior. The same was stated by Handojo (2002: 17) that autistic children with language disorders have communication difficulties both sign communication and language communication (verbal) and nonverbal can be difficulties or delays in the development of speech or language. Thus, it can be concluded that children with autism are children who experience abnormalities in the development of verbal and nonverbal communication.

According to diagnoses in the field of neurobiology and genetics, it has been found that there is a specific damage in the limbic system of autistic patients, namely in the part of the brain called the hypocampus and amygdala. When seen from the number of autistic patients, based on the results of research from Siegel, B (1996: 12); Sutadi (1997: 13); Widyawati (2001: 
1) explained that the prevalence or emergence of autistic children is estimated at 10 children to 15 autistic children out of 10,000 school-age children. In addition, according to SES (2002: 35) based on international research results indicate that the prevalence of autistic children is increasing with a ratio of 10: 1000. That is, every thousand normal children there are ten children with autistic disorders. Likewise in Indonesia, Nugroho (2011: 1) asserted that according to neurologists the number of autistic patients was quite large. The prevalence of autism spectrum disorders is quite high with a ratio of 8: 1000. In fact, Wijayakusuma (2009) predicts that the number of autistic children in 2010 reaches $60 \%$ of the total child population worldwide. This certainly needs special attention.

The earlier treatment will produce a better prognosis. In the National Institute of Mental Health (2008) it is realized that the handling of children with autism cannot be equated with one another. Two important points for handling autistic children are at the earliest possible time and individual programs that fit the child's needs. Furthermore, Prasetyoningsih (2014) states that therapists from the Royal College of Speech and Language explain that language developmental and pragmatic disorders are obstacles that can hinder effective communication. For this reason, researchers try to find several methods that can improve the language skills of children with autism. For that, start helping children with autism early on. Enabling young children as early as possible to be able to interact better with others can make a big difference throughout their lives because children support learning and further development. Delaney (2010: 1) explains that games are known as businesses that benefit children with neurological disabilities, including autistic children. Through games, children with autism will be more involved in social intrusion.

However, in therapeutic activities, the therapist certainly uses speech acts. Speech act theory according to Searle (in Rohmadi, 2004: 29) is a product or result of a sentence in certain conditions which can be in the form of statements, questions, orders or others. This speech act has the form, function, usage strategy, and selection strategy that must be adjusted by the speaker to the interlocutor and in what situations so the interlocutor can do and respond to the intent of the speaker. The use of speech acts has been known as language production. In this study, the therapist will help children with autism understand language through speech acts "touch". The "touch" speech act referred to is the inclusion of nonverbal language, such as facial expressions, gestures, and pralinguistic language in the method of playing the red light, green light in the intervention process.

Based on the speech acts used by the therapist when applying therapeutic methods, children will increase their vocabulary and learn to interact with others. Autistic children will also be taught about the context or situation of communication through directive and expressive speech acts through activities that can enhance basic language concepts related to visual cues. So this activity will link language and movement to strengthen language acquisition.

However, in every intervention of an autistic child, the therapist has not used references about the language used for autistic children. This was explained by Prasetyoningsih (in Litera, 2016, Vol. 15) that in general, therapists use references about autism in general and have not provided clinical communication references in autism interventions. This is because there is no specific reference to speech acts of therapy. 


\subsection{Speech Acts}

\section{Review of Literature}

Language is referred to as the communication medium used by a person or group of people, both in a small scope or a wider scope. The main function of language is as a means of communication. In communication, one purpose or one function can be spoken with various forms of speech. For this reason, the function of speech is reviewed in speech act theory. Searle, 1969 (in Defina, 2018: 71) says the speech act is the basic unit of communication. That is, in communication there are various units and speech acts this is the most basic part (unit) of communication. According to Searle (1969) in all linguistic communication there are speech acts. He argues that communication is not just a symbol, word or sentence, but it would be more appropriate if it is called a product or result of a symbol, word or sentence which is in the form of a speech performance (fire performance of speech acts). Speech act is a pragmatic analysis, which is a branch of language that examines language from its actual usage aspect. Speech act is a central entity in pragmatics and is also the basis for the analysis of other topics in this field such as presupposition, participation, conversational implicative, cooperation principle and politeness principle. Then, it can be concluded that the act of speech is a speech containing questions, statements, orders, or other that aims to state the intent in accordance with certain situations.

\subsection{Autism Child}

Autistic children are an integral part of extraordinary children. Autism comes from the word auto which means everything that is self-directed. Subyantoro (2013: 48) said that autism can also be interpreted as a defect in human neurological and psychological development, both from the fetus onwards, which causes weakness or differences in social interactions, communication skills, patterns of interest, and behavior.

One of the causes of autism is the dysfunction of the nervous system in the brain, in addition to causing problems in learning and language, children with autism have problems developing the ability to process information received through the senses. This statement was emphasized by Handojo (Subyantoro, 2013: 48) that autistic sufferers have some characteristic symptoms that can be seen from communication disorders, social interactions, behavior, emotions, and sensory. National Institute of Mental Health, 2008 (in Ballerina, 2016: 246) also confirms that autism is one of the developmental disorders of children. This disorder is shown by the lack of ability of children to the ability of social interaction, verbal communication and the presence of repetitive behavior. Therefore, it can be concluded that the disorder in autistic children lies in communication disorders, both verbal and social behavior so that autistic children find it difficult to obtain information and develop it.

\section{Language Disorders of Autistic Children}

Autism is a language disorder commonly known as Autism Spectrum Disorder (ASD). This autistic child experiences disruption in social life and communication. This was confirmed by Smith (in Indah, 2017: 114) that ASD has unique abilities, symptoms, and difficulties both in terms of social skills, communication and behavior. In the case of autism there is a combination of cognitive and social disorders.

People with autism can be silent until the age of five, or just parrot the words of an adult they hear. This indicates that people with autism have a limited natural mind, meaning they are unable to understand the world from the perspective of others. All aspects of communication 
are difficult to achieve for persons with autism, except the phonological aspects which some people can still master. The development of language skills not only experienced delays but also deviations. Phonologically, the articulation is quite clear although there are often various errors in the mention of objects. Likewise, morphological abilities often lead to errors. For example substitution or mentioning in other words, eliminating certain syllables, assimilation with other words, adding to the wrong syllables. The intonation tends to be flat and wrong in emphasizing speech.

\title{
2.3 Red Light and Green Light Games
}

\author{
Place : indoors \\ Equipment : Two sheets of folding paper (red and green) \\ Way
}

1. Teach children that green means "Way" and red means "Stop".

2. Ask someone to hold and show red or green paper; let the child know that green means the way and red means stop.

3. You will hold your child's hand and move or stop with the child. When moving, say "Green Light" continuously. Make a stop motion that is made excessive and say, "Red light". Many children understand this concept quickly because you associate movement with color and words.

4. Stand a few steps in front of the child. Show red paper to indicate "stop" and green paper to indicate "road" alternately. You might also need to say, "Stop" and "way" to associate verbal cues with visual cues.

Way (Involves playmates)

1. Choose a child as an officer who shouts "Green Light" and "Red Light" while brandishing cards.

2. Line up all participants approximately less than six meters from the officer.

3. When the officer shouts "Green Light" all children must jump up and down in the direction of the officer until the officer says "Red Light". During "Red Light" all participants must stop jumping.

4. Participants who are closest to the officer will become officers in the next round.

\section{Purpose :}

1. Body control: The use of the Happily Hop ball helps children improve stop / walk control on their bodies.

2. Instructions for confusion: All participants learn to follow voice and visual instructions.

3. Language concepts: This game enhances basic language concepts related to the visual instructions of the concepts. This game also fosters development in paying attention to others who are talking and following directions.

4. Preschool skills: Combining movement with color increases children's understanding of the concept of green meaning "walk" and red means "stop".

5. Proprioceptive nature: Jumping up and down, as well as stopping / walking, increasing input to the joint.

6. Social interaction: This activity is a good game to encourage children to participate with playmates because this activity is a sensory motor activity with clear goals, accompanied by minimal interaction, but with shared excitement. 


\subsection{Speech Acts "Touch" Autistic Child Therapists}

Speech act refers to the activity of speaking / uttering speech with a specific purpose. Purwo (in Ristiyani 2016: 44) states that the speaker does not merely say something by saying an expression. In the pronunciation of that expression he also acted on something. In other words, speech acts are activities that utter or speak utterances with a specific intention that are speech acts or word acts.

When linked to autistic child communication, Susman (in Yuwono, 2009: 7) explains that the development of an autistic child is influenced by several factors namely the way children interact, the way children communicate, the reasons behind the communication made by children and the level of understanding of children. Furthermore, there are four developments in communication of autistic children, namely first, the own agenda stage, second, the requester stage, third, the early communication stage, and fourth, the partner stage.

However, in concept, communication in children with autism must reach a stage where autistic children are able to talk and express themselves and engage in social interactions. To achieve this, of course, children with autism must be familiarized with utterances that are related to the context or situation. Although basically, this is a problem in the language processing of children with autism. They find it difficult to translate an expression into words.

One way that can be done to help autistic children increase their vocabulary intake, namely by involving autistic children in a therapeutic activity. In this activity, children with autism will be guided by therapists who have met the criteria for children with autism, such as having sufficient competence to deal with autistic children, have an interest or interest to be involved in the life of an autistic child, have a high level of patience, and have a tendency to always learn something new because this field of autism is a new field that is always developing. This is certainly related to how autistic children communicate that must be repeated so that the therapist must be able to choose the right speech act and do it repeatedly until the speech is able to add to the vocabulary of autistic children.

\section{Research Methodology}

This research is classified as a qualitative research with analytic-descriptive method. Descriptive method aims to make a description of the object of study in a systematic, factual, and accurate manner about the data, the characteristics and the relationship of the phenomena under study, so as to obtain a scientific picture of the data. Analytical methods are used to determine the causal relationship between two variables in an observational manner, where the form of a relationship can be in the form of differences, relationships, or influences. This method is used to find out the learning outcomes of autistic children in "touch" speech therapists in the method of playing the red light, green light for verbal communication of autistic children at the Intervention Service for Autism and Development Delay Foundation (YISADDI).

This research was conducted at the Intervention Service for Autism and Development Delay Foundation (YISADDI) in June 2019. The research subjects in this study were therapists and children with autism and the object was a speech act of therapists at the Intervention Service for Autism and Development Delay (YISADDI) Foundation. 


\section{Discussion}

From the results of the study, directive speech acts used by therapists seem to be consistent so that autistic children easily understand the utterances of the therapist. Not only therapists, parents of autistic children use the same words as the words used by therapists.

Distribution of directive speech acts used by therapists in verbal communication of autistic children at the Intervention Service for Autism and Development Delay Foundation (YISADDI)

Table 1. Expressive speech acts, Tindak tutur ekspresif

\begin{tabular}{|l|c|c|c|c|c|c|c|c|c|}
\hline Form of Speech Act & 1 & 2 & 3 & 4 & 5 & 6 & 7 & 8 & 9 \\
\hline Directive & 34 & 10 & 6 & 28 & 2 & - & - & - & - \\
\hline Percentage (\%) & $42,5 \%$ & $12,5 \%$ & $7,5 \%$ & $35 \%$ & $2,5 \%$ & & & & \\
\hline
\end{tabular}

Note: (1), invite/encourage (2), reject/prohibit (3), ask (4), approve (5), ask (6), order (7), advise (8), recommend (9) and etc

Expressive actions are speech acts that express feelings or expressions of the therapist's moods. Expressive functions include the function of praise and thank. The function of praise is used to give praise or appreciation for the positive responses and actions of children with autism.

Expressive speech acts of praise are often done by therapists in interventions. Speech praise is marked by the use of speech "smart", "great", "good", "right", and "good". The use of the ABA method requires the therapist to use a lot of praise for autistic children because this method makes the reward a way of treating the therapist. In clinical intervention activities therapists often use praise speech with the aim of encouraging and praising the positive actions of children with autism.

Furthermore, expressive speech acts in the form of thanksgiving or thanksgiving speeches are marked by the expression "thank you". The thanking function is used to say thank you for the responses and actions of an autistic child that is in line with the therapist's expectations.

In clinical intervention autistic children expressive function has an educational content. Praising is a form of reinforcement (reinforcement) of what is done by children with autism. In clinical intervention activities, the therapist does not give punishments when an autistic child makes a mistake. In the language of therapists there is no violence. The therapist gives a positive appreciation for the correct actions of children with autism by praising, appreciating, or saying thank you.

Although therapy has provided reinforcement for every positive action from an autistic child, the therapist has not yet received a proud expression of what the child has achieved him. After successfully doing one activity, children with autism just keep quiet and try to take other activities that are not included in therapeutic activities. So to anticipate this, the therapist continues to oversee the work of children with autism and immediately gives appreciation when an autistic child has completed its activities. From this incident it can be said that children with autism have not been able to deliver a speech act that expresses their expression. This relates to the characteristics of children with autism, namely deviant behavior or delays in language 
and communication skills. Therapeutic programs and behavioral interventions can be applied to develop speech skills, especially expressive speech acts.

Distribution of expressive speech acts used by therapists in verbal communication of autistic children at the Intervention Service for Autism and Development Delay Foundation (YISADDI)

Table 2.

\begin{tabular}{|l|l|l|l|l|l|l|}
\hline Form of Speech Act & 1 & 2 & 3 & 4 & 5 & 6 \\
\hline Expressive & 15 & 3 & - & - & - & - \\
\hline Percentage (\%) & $83,3 \%$ & $16,6 \%$ & & & & \\
\hline
\end{tabular}

Note: Expressive speech acts of kind thanking (1), congratulating (2), apologizing (3), blaming (4), praising (5), condolence (6)

In contrast to normal speakers who have the same age as autistic children in this study, which is around the age of 4-8 years whose speech acts only use direct speech act strategies right on target. Susanto (in the journal As-salam, 2015: 59) stated that children aged 7 years 10 months have been able to deliver their utterances with direct speech act strategies directly to the target, reason / argument, and indirect speech act strategies with seduction and threat modes.

Table 3. Speech Act Strategies for Autistic Child

\begin{tabular}{|l|l|l|}
\hline No. & Therapist Speech Strategy & Indicator \\
\hline 1. & Summon strategy & Direct calling the child's name \\
2. & Guiding strategy & Provision of direct and clear instructions \\
3. & Visual strategy or model & $\begin{array}{l}\text { Direct examples through demonstrations, } \\
\text { drawings and movements }\end{array}$ \\
\hline
\end{tabular}

The selection of speech acts is based on components from the Hymes theory (via Nadar, 2009: 7) and Blanchet (2008: 4), the components known as SPEAKING: Settings and Scenes (time and place), Participants, Ends ), Act of Sequence, Keys (ways), Instrumentalities (media), Norms (norms), and Genres (types) cannot be separated from the therapist's attention. Based on the results of interviews conducted with six therapists at the ISADDI Foundation, the therapist must first recognize who the speech participants are and the abilities of their clients through observation by the foundation's psychology team. After knowing who the client is, the therapist intervenes through therapeutic actions using the dominant method of play. During therapeutic activities, the therapist uses speech acts in a simple, clear, and straightforward pattern. The use of communication-picture (Compic) and picture exchange communication (PECS) by the therapist is a medium that helps the therapist to convey the purpose of his speech to avoid confusion in children with autism.

The content and method of speech messages delivered to children with autism are delivered by the therapist using language that has been taught to children. Then the delivery process is done with simple instructions and uses persuasion and visual cues so that they understand what the meaning of a therapist's speech.

The content and method of speech messages delivered to children with autism are delivered by the therapist using language that has been taught to children. Then the delivery process is done with simple instructions and uses persuasion and visual cues so that they understand what is the meaning of a therapist's speech. 
Autistic children who are included in clinical pragmatic studies experience disorders of the brain nerves in the language part of the hippocampus and amygdale. When viewed from physical characteristics, children with autism look like other normal children, only the characteristics that are most visible in them are eye contact and expression. They are very difficult to focus on a matter and tend to withdraw social environment. Furthermore, the expression seemed flat. That is because those who are unable to master the atmosphere around it.

Autistic children must be introduced to language even if they experience vocabulary deficits and pragmatic deficits. The therapeutic process undertaken is an effort to overcome the problems that occur in them. The therapist who teaches uses speech acts that have been adapted to the child's abilities. However, in communicating with children with autism, the therapist does not merely speak but also needs to use additional media, such as PEC, compic and various playing instruments.

In addition, from the results of observations that have been made and observations of therapeutic activities undertaken by therapists in children with autism, therapists cannot just use speech in introducing language to children. Languages that are introduced by various methods of play, especially the method of playing red lights, green lights, require repeated recognition. The therapist also uses "touch" in each of his speech acts. "Touch" in question is the facial expression that is tailored to the therapeutic situation, voice intonation, and prompts. Example:

Context: Therapists teach children to play red light, green light

T: Come on stand up. Imitate! Red stopped (while holding an autistic child).

A: (Follow therapist's instructions)

T: Red stopped. Green goes. (While holding an autistic child to demonstrate the game)

A: (Following instructions)

T: Smart. Can get crackers. It's delicious

A: (Eats crackers).

T: OK. Now save the card. Naah. Please save.

A: (whining)

In the utterance above, the therapist invites children with autism and practices together the newly introduced game. Therapists will always provide assistance to children with autism when they begin to lose focus or start confused. The action is a prompt given by the therapist so that the autistic child responds quickly to instructions from the therapist.

Context: Therapists introduce autistic children how to play red lights, green lights.

T: Come on stand up. (Pulling the child's hand to stand). Green goes (demonstrate the game). Imitate! Go green.

A: (Walks over the therapist)

T: Red stop.

A: (Imitating therapist)

Q: Hold the door (Shows a green card). Go (Showing a red card) Stop.

A: (Instructs correctly)

T: Great. (Gives crackers)

Q: Hold the mirror (shows a green card). Go (Showing a red card) Stop. Yes, smart. (While patting the shoulder of an autistic child). You can get crackers. Sit here

From the data above, the therapist praises autistic children with cheers and proud faces for the achievement of autistic children. The compliment is accompanied by a pat on the child's 
shoulder and a reward. In accordance with the opinion of Djatmika (in the JRR journal, 2012: 131) which states that most of the speech acts carried out by the teacher are realized in the mood structure in the form of ellipsis construction.

The delivery of speech acts is related to non-verbal actions in the intervention of autistic children, both therapists and autistic children use three types, namely body language, facial expressions, and paralinguistic aspects that are used together with verbal actions. The therapist always makes eye contact with an autistic child when he initiates exchanges and interacts with him. All of these non-verbal actions are one of the factors of language exploitation that makes the process of transferring skills effective. To make the interaction more effective, the therapist also exploits the paralinguistic aspect for most of the actions taken.

\section{Discussion}

Forms of directive and expressive speech acts are used by autistic child therapists to communicate based on the characteristics of autistic children and each speech must be structured, patterned, programmed, consistent, and continuous. Speech acts used are simple patterns and consist of one word. Types of directive speech acts used by therapists include commanding, inviting or pleading, banning, asking short and closed questions, and agreeing.

Next, the expressive speech acts used by the therapist are praise and thanksgiving. In clinical intervention autistic children expressive function has an educational content. Praising is a form of reinforcement (reinforcement) of what is done by children with autism. In clinical intervention activities, the therapist does not give punishments when an autistic child makes a mistake. In the language of therapists there is no violence. The therapist gives a positive appreciation for the correct actions of children with autism by praising, appreciating, or saying thank you.

The speech act strategy used by the therapist is a direct speech strategy (literal) through a calling strategy (diversion of focus), a hinting strategy, and a visual or model strategy. The calling strategy is carried out by the therapist by calling the child's name directly to get the child's attention or focus.

The choice of speech acts for autistic children uses speech acts components, namely SPEAKING: Settings and Scenes (time and place), Participants, Ends, Acts of Sequence, Keys, Instrumentalities (Instructions) media), Norm (norm), and Genres (type). Data collection was carried out through interviews. Settings and scenes were carried out on therapeutic activities using the red light, green light play method and carried out at the child's home. Participants in the intervention in autistic children are therapists who have special psychology and education graduates' qualifications and autistic children who have known their abilities through examinations by foundation psychology, interviews with parents, direct observation of children, and assessment.

Ends (goals) communication between autistic children and therapists is done by using communication-picture (compic) and picture exchange communication (PECS) as communication media so that the purpose or purpose of communication can be achieved. The Act of Sequence is carried out through commands that have previously been taught to children. Furthermore, the therapist accompanies the speech with persuasion so that the child understands what the message is delivered by the therapist.

For the components of keys, the therapist uses attitudes, tones, and ways of speaking that are clear, non-rigid, polite, avoiding angry tones, and adjusting to the parent's speaking 
style. The Instrumentalities component is carried out by the therapist by choosing languages that are often used daily. Furthermore, the therapist combines it with PECS and compic if an autistic child has difficulty in getting the point out of his speech.

In the Norms component, the therapist chooses polite speech, such as greetings for each family member, caregiver, therapist, and visiting guests. In addition, the therapist also teaches spoken words such as saying the word help when they want something. For the genre component, the therapist uses the speech genre, namely by using polite language, not rigid, and using PECS and compics.

\section{References}

Ariffudin. 2010. Neuropsikolinguistik. Jakarta: Rajawali Pers.

Arikunto, Suharsimi. 2006. Prosedur Penelitian: Suatu Pendekatan Praktik. Jakarta: PT Rineka Cipta.

Ballerina, Titisa. 2016. Meningkatkan Rentang Perhatian Anak Autis Dalam Pembelajaran Pengenalan Huruf. Dalam Jurnal INKLUSI: Journal Of Disability Studies Vol. 3, No. 2, H.245-266 DOI: 10.14421/Ijds.030205.

Blum-Kulka, S., Kasper, G., \& House, J. (1989). Investigating cross cultural pragmatics. New Jersey: Norwood.

Brown, Penelope dan Stephen Levinson. 1987. Politeness: Some Universal Language. Cambridge: Cambridge University Press.

Chaer, A. \& Agustina, L. 2004. Sosiolinguistik: Perkenalan Awal. Jakarta: Rineka Cipta.

Defina. 2018. Tindak Tutur Ekspresif Pada Anak-anak saat Bermain Bola di Lapangan Expressive Speech Acts Among Children When Playing Football In The Field. Ranah: Jurnla Kajian Bahasa. Vol. 7. No. 1. p. 69-85.

Delaney, Tara. 2010. 101 Permainan dan Aktivitas untuk Anak-anak Penderita Autisme, Asperger, dan Gangguan Pemerosesan Sensorik. Yogyakarta: Andi Yogyakarta.

Djatmika,dkk.2012. Eksploitasi Bahasa pada Pengajaran Anak Autis. JRR, No.2,126-141.

Granpeesheh, Doreen. 2014. Evidence-Based Treatment For Children With Autism: The Card Model. Academic Press.

Handojo . 2002. Autisme . Jakarta: PT. Bhuana Ilmu Populer.

Indah, Nur Rohmani. 2017. Gangguan Berbahasa Kajian Pengantar. Malang: UIN-Maliki Press.

Kresno S, Ella Nurlaela H, Endah Wuryaningsih, Iwan Ariawan. 1999. Aplikasi Penelitian Kualitatif dalam Pencegahan dan Pemberantasan Penyakit Menular, Fakultas Kesehatan Masyarakat Universitas Indonesia bekerja sama dengan Direktorat Jenderal Pemberantasan Penyakit Menular dan Penyehatan Lingkungan Pemukiman Depkes RI. Jakarta.

Krueger, Richard A. 1988. FOCUS GROUPS: A Practical Guide for Applied Research. SAGE Publications. California.

Leech Geoffrey. 2011. Prinsip-Prinsip Pragmatik. Jakarta : UI-Press.

Mahsun. 2005. Metode Penelitian Bahasa: Tahapan Strategi, Metode, Dan Tekniknya. Jakarta: PT. Raja Grafindo Persada.

Moleong, L. J. (2009). Metode Penelitian Kualitatif. Jakarta: Universitas Indonesia.

National Institute Of Mental Health. (2008). Autism Spectrum Disorders Pervasive Developmental Disorders. Bethesda: National Institute Of Mental Health Science Writing. Press \& Dissemination Branch. 
Nugroho. 2011. Mensos Dukung Pembuatan Film Dokumenter Autisme. http://www. rri.co.id/index.php. download, 27 April 2011.

Obler, L.K. \& Gjerlow, K. 2000. Language And The Brain. Cambridge: Cambridge University Press.

Rachman. 2015. Tindak Tutur dalam Proses Belajar-Mengajar pada Taman Kanak-kanak Dharma Wanita Kelurahan Wapunto Kecamatan Duruka Kabupaten Muna (Kajian Pragmatik). Jurnal Humanika No. 15, Vol. 3.

Ristiyani. 2016. Tindak Tutur Santun sebagai Strategi Pemilihan Bahasa untuk Komunikasi Konselor yang Efektif. Jurnal Konseling GUSJIGANG Vol. 2 No. 1.

Rohmadi, Muhammad. 2004. Praktik Teori Dan Analisis. Jogjakarta: Lingkar Media.

Sastry, Anjali. Blaise Aguirre. 2012. Parenting Anak dengan Autisme: Solusi, Strategi, dan Saran Praktis untuk Membantu Keluarga Anda. Yogyakarta: Pustaka Pelajar.

Searle, J.R. 1969. Speech Acts: An Essay In The Philosophy Of Language. Cambridge: Cambridge University Press. J.O.Urmson.

Simanjuntak, Mangantar. 2009. Pengantar Neuropsikolinguistik: Menelusuri Bahasa, Pemerolehan Bahasa, dan Hubungan Bahasa dengan Otak. Medan: Perpustakaan Republik Indonesia.

Specialist Education Service (SES). Minister of Education New Zealand. 2002. Autistic Spectrum Disorders (ASD): A Resource for Teachers. ABILL Publishing. New Zealand.

Subyantoro. 2013. Gangguan Berbahasa Mengenali Untuk Mengantisipasi Sejak Dini. Yogyakarta: Ombak Press

Sudaryanto. 1993. Metode dan Aneka Teknik Analisis Bahasa. Yogyakarta: Duta Wacana University Press.

Sugiyono .2011. Metode Penelitian Kuantitatif, Kualitatif, dan R\&D. Bandung: Alfabeta.

Sukardi, Edi. 2005. Kecerdasan Tutur Bahasa. Jakarta: Educatio Indonesia, Vol. 13, No. 1.

Suteja, J. (2014). Bentuk Dan Metode Terapi Terhadap Anak Autisme Akibat Bentukan Perilaku Sosial. Jurnal Edueksos, III(1), 119-133.

Tarigan, Henry Guntur. 2009. Pengajaran Analisis Kontrastif Bahasa. Bandung: Angkasa.

Usman, F.S. 2008. Fungsi Kortikal Luhur. Www.Fritzsumantri. Blogspot.Com accessed on 4 Juli 2011.

Wijana, I Dewa Putu. 1996. Dasar-dasar Pragmatik. Yogyakarta: Andi Publisher

Wijayakusuma, Hembing. 2008. Psikoterapi Anak Autisma. Teknik Bermain Kreatif Nonverbal dan Verbal. Terapi Khusus Untuk Autisma. Jakarta: Pustaka Populer Obor.

Wiranty, Wiendi. 2015. Tindak Tutur Dalam Wacana Novel Laskar Pelangi Karya Andrea Hirata (Sebuah Tinjauan Pragmatik). Jurnal Pendidikan Bahasa, Vol. 4, No. 2.

Yuwono, Joko. 2009. Memahami Anak Autistik (Kajian Teoritik dan Empirik). Bandung: Alfabeta. 